\title{
Comparative study of induction of labour with dinoprostone gel versus mechanical dilatation in unfavorable cervix (low Bishops Score)
}

\author{
Gayatri Mathuriya, Sharad Pratap Singh Kushwaha, Shweta Pradhan*
}

Department of Obstetrics and Gynecology, MGM Medical College and MY Hospital, Indore, Madhya Pradesh, India

Received: 05 July 2017

Revised: 05 August 2017

Accepted: 18 August 2017

\section{*Correspondence:}

Dr. Shweta Pradhan,

E-mail: shwetapradhan22@gmail.com

Copyright: (C) the author(s), publisher and licensee Medip Academy. This is an open-access article distributed under the terms of the Creative Commons Attribution Non-Commercial License, which permits unrestricted non-commercial use, distribution, and reproduction in any medium, provided the original work is properly cited.

\begin{abstract}
Background: Induction of labour is a common procedure in obstetrics, occurring in upto $30 \%$ of pregnancies. Objective of present study was to compare the efficacy of double balloon transcervical catheter to that of a PG vaginal insert among women undergoing labour induction in terms of singleton pregnancies of both nulliparous and multiparous women with an unfavorable cervix.

Methods: Patient admitted for induction of labour were randomized to receive intravaginal dinoprostone or intracervical Foley's catheter. Patient not entering active labour and having rupture membranes or arrest of dilatation received IV oxytocin.

Results: 150 patients received dinoprostone gel (group A) and 150 patients received Foleys catheter no.18 (group B). The mean time until cervix ripening was less in group A group (0.0001-p value). The mean time until vaginal delivery was less in the Group A group (p value-0.010) among vaginal deliveries more patients in the Group A group delivered within 24 hours (0.0001-P value.). There was significant differences in cesarean delivery rates $(8 \%$ vs $20.66 \%$, P value-0.0001, sig). Oxytocins is required in both groups $(73.33 \%$ vs. $78.66 \%)$.

Conclusions: Group A was associated with more rapid cervical ripening, shorten induction to vaginal delivery interval and greater no. of vaginal deliveries within 24 hours.
\end{abstract}

Keywords: Cervix ripening, Foleys catheter, Labour induction, PG

\section{INTRODUCTION}

Induction of labour is a common procedure in obstetrics, occurring in upto $30 \%$ of pregnancies. ${ }^{1,2}$ Induction of labour can be defined as the artificial initiation of labour, before its spontaneous onset, for the purpose of delivery of the fetoplacental unit. ${ }^{3,4}$ The most common reasons for induction of labour are post term pregnancy, diabetes, maternal request and hypertensive disease of pregnancy. ${ }^{3,5}$ This state of cervix before induction, as measured by Bishop score, has been shown to be an important determinant of the success or failure of induction. ${ }^{6}$ There are two categories of artificial means of cervical ripening prior to labour induction - mechanical (the Foleys catheter balloon and laminaria tent) and pharmacological (PGE1, PGE2, PGF2 alpha, estrogen) mechanical device dilate the cervix by accessing the fetal membrane, and pharmacological preparation cause connective tissue softening, cervix effacement and uterine activity..$^{4-8}$ Despite the multiplicity of techniques, there is no universally accepted idea thus the ideal method of labour induction remains elusive. ${ }^{9,10}$ Several studies show mechanical ripening with foley bulb to be atleast as effective as other methods of ripening with no increase in maternal and fetal morbidity. ${ }^{11-14}$ On the other hand PGs are effective agent for cervical ripening. ${ }^{15,16}$ 
PGs in general, special PGE2 have been extensively studies for clinical use, for cervix ripening and labour induction. ${ }^{17,18}$

The objective of present studies were twofold to compare the efficacy of dinoprostone gel and Foleys catheter in induction of labour and to compare the adverse effect of these two regimens with respect to hyper stimulation of uterus, signs of fetal distress (i.e. an abnormal CTG, pattern of the presence of meconium in the amniotic fluid), the frequency with which instrumental delivery (including cesarean section is required, the necessity for augmentation with oxytocin and the neonatal outcome (i.e. the Apgar score and nursery admission).

\section{METHODS}

This prospective randomised study was conducted in the department of obstetrics and gynaecology, Maharaja Yashwant Rao Hospital Indore, M.P. The study was approved by the ethical committee of the institution. The study was conducted between September 2014 and September 2015. Induction of labour employing cervical administration of dinoprostone (PGE2) or cervical dilatation by Foleys catheter (bard catheter) were compared. The criteria for inclusion were pregnancy between 37 to 42 weeks gestation, had a singleton pregnancy with the fetus in vertex presentation, with one or more of the common indication for induction of labour including post term pregnancy, premature rupture of membrane, preeclampsia, oligohydramnios, diabetes and psychological parameters. In additions, absences of spontaneous contraction and Bishop score of equal or less than 5 were also required. The criteria applied for exclusion from the study where contraindication for the administration of PG and/or for vaginal delivery, or previous caesarean section or other form of uterine surgery, breech presentation, signs of infections and or the necessity for immediate delivery as indicated by, for example, pathological CTG at the time of admission. Who fulfilled appropriate criteria were invited to participate in the study and those who agreed gave there informed consent.

The women assigned to dinoprostone group, received $2 \mathrm{mg}$ of dinoprostone gel intracervically. The women in the $2^{\text {nd }}$ group a Bard catheter no. 18 was inserted through the cervical canal with visualization of the cervical os during examination with a speculum. Once past the internal os, the balloon was filled with $50 \mathrm{ml}$ of sterile water and the catheter tapped to an inner thigh to maintain traction. The position and traction of balloon were checked on once or twice on each hour and the catheter remained in place until the balloon was expelled spontaneously.

All the women were monitored clinically for the progress of labour and fetal wellbeing. Partogram was maintained in all cases. When the Bishop score attained a value of equal to or more than 7 , the membranes were ruptured artificially or, in cases of preterm rupture, oxytocin were administered if necessary. If Bishops score remains unfavorable equal or less than 5 after 18 hours of treatment in any group there $\mathrm{m} / \mathrm{m}$ in those patients was further individualized.

The primary outcome measure was induction to delivery interval. Secondary outcome was the incidence of instrumental delivery (including cesarean section), uterine hyper stimulation with or without abnormalities in Fetal heart rate, staining of the amniotic fluid with meconium requirement for augmentation with oxytocin and occurrence of postpartum bleeding. The neonatal outcome recorded were the apgar score $5 \mathrm{~min}$. after birth a necessity for admission to the neonatal intensive care unit.

\section{Statistical analysis}

The groups were compared by using chi square test and unpaired student $\mathrm{T}$ test. Statistical significances were defined as $\mathrm{P}<0.05$.

\section{RESULTS}

A total of 300 women with gestational ages of 37-42 wks were enrolled in this study. Of the 300 pregnant women, 150 were assigned to the PGE 2 group and 150 to the foley's group.

Table 1: Base line characteristics.

\begin{tabular}{|c|c|c|c|}
\hline & Group 1 & Group 2 & P value \\
\hline Maternal age & $23.54 \pm 3.43$ & $24.2 \pm 4.22$ & 0.097 (not sig) \\
\hline \multicolumn{4}{|l|}{ Gravidity } \\
\hline G1 & $52 \%(78)$ & $42.66 \%(64)$ & 0.006 (sig) \\
\hline $\mathrm{G} 2$ & $31.33 \%(47)$ & $34 \%(51)$ & 0.006 (sig) \\
\hline G3 & $14 \%(21)$ & $12.67 \%(19)$ & 0.006 (sig) \\
\hline G4 & $2.67 \%(4)$ & $10.67 \%(16)$ & 0.006 (sig) \\
\hline \multicolumn{4}{|l|}{ Parity } \\
\hline $\mathrm{P} 0$ & $56.67 \%(85)$ & $46 \%(69)$ & 0.006 (sig) \\
\hline $\mathrm{P} 1$ & $29.33 \%(44)$ & $37.33 \%(56)$ & 0.006 (sig) \\
\hline $\mathrm{P} 2$ & $10 \%(15)$ & $13.33 \%(20)$ & 0.006 (sig) \\
\hline P3 & $4 \%(6)$ & $3.34 \%(5)$ & 0.006 (sig) \\
\hline
\end{tabular}

Baseline characteristics of both groups were similar including age, gravidity, parity. The mean gestational age was statistically higher in the PGE2 group; however, this was clinically not significant. Overall indication for induction were also similar across intervention apart from more small for gestational age (SGA) or IUGR induction being performed with Foleys catheter. Additionally, cervical station at the time of induction did not differ across intervention group.

In both groups, considerable improvement occurred in Bishop score 6 hours after initiation of induction, but this progress in PGE2 group was greater than Foleys ( $P$ $=0.002, \mathrm{~s})$. The mean time for initiation of the induction 
to active phase of labour in PGE2 group was shorten (4.58 \pm 2.11 hour, Foleys group 7.45 $\pm 3.4, \mathrm{P}=0.001$ ).

Table 2: Labour profile.

\begin{tabular}{|llll|}
\hline Variables & Group 1 & Group 2 & P value \\
\hline $\begin{array}{l}\text { Initial bishop } \\
\text { score }\end{array}$ & $2.26 \pm 0.76$ & $2.34 \pm 0.81$ & $\begin{array}{l}0.341 \\
\text { (not sig) }\end{array}$ \\
$\begin{array}{l}\text { Bishop } \\
\text { score>6hrs } \\
\text { after induction }\end{array}$ & $8.34 \pm 2.13$ & $7.66 \pm 1.74$ & $\begin{array}{l}0.002 \\
\text { (sig) }\end{array}$ \\
\hline $\begin{array}{l}\text { Duration from } \\
\text { initiation of } \\
\text { induction to } \\
\text { active phase of } \\
\text { labour (in hrs) }\end{array}$ & $4.58 \pm 2.11$ & $7.45 \pm 3.41$ & $\begin{array}{l}0.001 \\
(\mathrm{sig})\end{array}$ \\
$\begin{array}{l}\text { Duration from } \\
\text { cervix ripening } \\
\text { to delivery }\end{array}$ & $5.78 \pm 2.59$ & $6.86 \pm 4.37$ & 0.010 \\
(sig)
\end{tabular}

The Table 2 illustrate interval time from beginning of cervical ripening to vaginal delivery in both groups. Group 1 required $4-7$ hours $(72.66 \%)$ and group 2 required 6-11 hours (62\%). There was significant difference in the caesarean rate and indication of caesarean between the two groups. The rate of caesarean section is more in group 2 as compared to group 1 (8\% vs $43 \%$, P value -0.0001 , statistically Significant). Most common cause of cesarean in group 2 was failed induction. In group 1, $12 \%$ of women had complication like fever, nausea, vomiting and UTI as compared to 6\% in group 2 which is statistically significant $(\mathrm{P}=0.002)$ UTI complications are more in Foleys catheter group and fever, nausea, vomiting was common in PGE2 group (Table 4).

Table 3: Maternal outcome.

\begin{tabular}{|lll|}
\hline Mode of delivery (P value-0.0001) & Group 1 & Group 2 \\
\hline Caesarean section & 12 & 31 \\
\hline Assisted vaginal delivery & 7 & 9 \\
\hline Vaginal delivery & 131 & 110 \\
\hline Indication for CS & Group 1 & Group 2 \\
\hline Non reassuring FHS pattern & 6 & 7 \\
\hline Failed Induction of labour & 6 & 24 \\
\hline
\end{tabular}

Table 4: Maternal complications.

\begin{tabular}{|ll|l|}
\hline $\begin{array}{l}\text { Maternal Complication (P } \\
\text { value-0.002) P value significant }\end{array}$ & Group 1 & Group 2 \\
\hline Meconium stained amniotic fluid & 8 & 10 \\
\hline Fever during delivery & 3 & 1 \\
\hline Hyperstimulation & 6 & 2 \\
\hline Nausea, vomiting & 13 & 1 \\
\hline UTI & 2 & 7 \\
\hline
\end{tabular}

No significant differences between the groups with respect to neonatal outcome were noted. On average $13.3 \%$ of neonates require admission to neonatal nursery or special care unit with significantly more admission in Foley's group ( $16 \%$ vs $10.67 \% \mathrm{P}=0.01$, Table 4 ).

Table 5: Neonatal outcome.

\begin{tabular}{|lll|}
\hline Neonatal outcome & Group 1 & Group 2 \\
\hline Apgar $\leq 4$ at min. & 1 & 2 \\
\hline Apgar $\leq 7$ at 5 min. & 19 & 23 \\
\hline Admission to NICU & 16 & 24 \\
\hline
\end{tabular}

Reasons for nursery admissions were divided into neonatal condition and fetal condition. Neonatal condition includes birth trauma, asphyxia, respiratory difficulties, and jaundice requiring phototherapy. Fetal condition was defined as growth restriction or congenital abnormalities.

As was expected, Bishop score improved significantly in both groups after treatment. The foley catheter intervention took a longer time than the Pg group to ripen the cervix, indicating more favorable outcome with PG a shorter ripening time and induction time with foley catheter has being reported in several studies.

An observation made in the study was a tendency towards more frequent Caesarean section is response to cervical dystocia among the women administered with the foleys catheter

\section{DISCUSSION}

Present study was undertaken to compare the efficacy and safety of twocommonly used method of induction of labour. Several studies (Asad J et al, Pennel C et al, Pragel AM et al) compared the efficacy and patient satisfaction of these two methods of induction but women studies are small and restricted to multiparous women.

St Onge and Connors showed that Foleys catheter takes more time in induction to delivery interval compared to prostaglandin, which is similar to the present study.

Present finding reveals that the interval of time between induction and delivery shorten with PgE2 than with the catheter. This conclusion was similar to that of Cochrane review of mechanical induction of labour published in 2001, which repeated that the catheter procedure has the same efficacy similar to that of administration of PGE1 but lower than PGE2. ${ }^{19}$ Similar to our observation, another recent study concludes that $50 \mathrm{mcg}$ dose of PGE1 is more effective than a balloon catheter in inducing labour with the same degree of safety. ${ }^{20}$

\section{CONCLUSION}

The result of present study shows that the intracervical PGE2 compared with Foleys catheter had greater success regarding cervical ripening, with labour induction shorter time of ripening, labour induction shorter time of delivery, shorter time to active phase of labour with an 
unfavourable cervix without increasing cesarean rate due to fetal distress or failure to progress.

Funding: No funding sources

Conflict of interest: None declared

Ethical approval: The study was approved by the Institutional Ethics Committee

\section{REFERENCES}

1. Laws PJ, Sullivan EA. Australia's Mothers and Babies 2002. AIHW Cat. No. PER 28. Sydney: AIHW National Perinatal Statistics Unit. (Perinatal Statistics Series No. 15) 2004.

2. National Collaborating Centre for Women's and Children's Health. Induction of labour. London, UK: RCOG Press;2008.

3. Joan Crane, St Jhon's NF, Line L, Gregory JR. Induction of labour at term. J Obstet Gynecol Can. 2001;23:717-28.

4. McEwan AS. Induction of labour. Obstet Gynecol Reprod Medicine. 2008;18:1-6

5. Vellekoop J, Vrouenraets FP, van der Steeg JW, Mol BW, Roumen FJ. Indications and results of labour induction in nulliparous women: An interview among obstetricians, residents and clinical midwives. Eur J Obstet Gynecol Reprod Biol. 2009;146:156-9.

6. Nicole W, Karjane, Ellen L, Brock, Scott W. Induction of labour using a Foley Balloon, With and Without Extra -Amniotic Saline Infusion. Obstet Gynecol. 2006;107:234-9.

7. Ghanaei MM, Sharami H, Asgari A. Labour induction in nulliparous women: a randomized controlled trial of foley catheter with Extra Amniotic saline infusion. J Turkish-German Gynecol Assoc. 2009;10:71-5.

8. Niromanesh S, Mosavi-Jarrahi A, Samkhaniani F. Intracervical Foley catheter balloon vs. prostaglandin in preinduction cervical ripening. Int $\mathrm{J}$ Gynecol Obstet. 2003;81:23-7.

9. Rouben D, Arias F. A randomized trial of extraamniotic saline infusion plus intracervical foley catheter ballon versus prostaglandin E2 vaginal gel for ripening the cervix and inducing labour in patient with unfavorable cervixes. Obstet Gynecol. 1993;82:290-4.

10. Venagalil SR, Guinn DA, Olabi NF, Burd L, Owen J. A randomized trial of misoprrostol and extraamniotic saline infusion for cervical ripening and labour induction. Obstet Gynecol. 1998;91:7749.
11. Barrilleaux PS, Bofill JA, Terrone DA, Magann EF, May WL, Morrison JC. Cervical ripening and induction of labour with misoprostol, dinoprostone gel, and a Foley catheter:A randomized trial of 3 techniques. Am J Obstet Gynecol. 2002;186;1124-9.

12. Culver J, Strauss RA, Brody S, Dorman K, Timlin S, Mc Mahon MJ. A randomized trial comparing vaginal misoprostol versus Foley Catheter with concurrent oxytocin for labour induction in nulliparous women. Am J Perinatol. 2004;21:139-46.

13. Guinn DA, Goepfert AR, Christine M, Owen J, Hauth JC. Extra-amniotic saline, laminaria, or prostaglandin E2 gel for labour induction with unfavourable cervix: a randomized controlled trial. Obstet Gynecol. 2002;187:847-52.

14. Mullin PM, House M, Paul RH, Wing DA. A comparison of vaginally adminie stered misoprsotol with extra-amniotic saline solution infusion for cervical ripening and labour induction. Am J Obstet Gynecol. 2002;187:847-52.

15. Charanchakul B, Herabutya Y. Randomised comparison of glycerol trinitrate and prostaglandin E2 for cervical ripening at term. Obstet Gynecol. 2000;96:549-53.

16. Herbutya YO, Prasertsawat P, Pokpirom J.A comparison of intravaginal misoprostol and intracervical prostaglandin E2 gel for ripening of unfavourable cervix and labour induction. J Obstet Gynecol Res. 1997;23:369-74.

17. Bugalho A, Bique C, Machungo F, Faundes. A Low dose vaginal misoprostol for induction of labour with a live fetus. Int J Gynecol Obstet. 1995;49:1149-55.

18. Wing DA, Rahall A, Jones MM, Goodwin TM, Paul RH. Misoprostol: an effective agent for cervical ripening and labour induction. Am J Obstet Gynecol. 1995:172: 1811-6.

19. Rayburn WF. Pre-induction cervical ripening: basis and methods of current practice. Obstet Gynecol Surv. 2002;57:683-692.

20. Zafarghandi AS, Baghaii NZ. Foley catheter cervical ripening with extraamniotic infusion of saline or corticosteroids: a double-blind, randomized controlled study. Acta Medica Iranica. 2004;42(5):338-42.

Cite this article as: Mathuriya G, Kushwaha SPS Pradhan S. Comparative study of induction of labour with dinoprostone gel versus mechanical dilatation in unfavorable cervix (low Bishops Score). Int J Reprod Contracept Obstet Gynecol 2017;6:4363-6. 